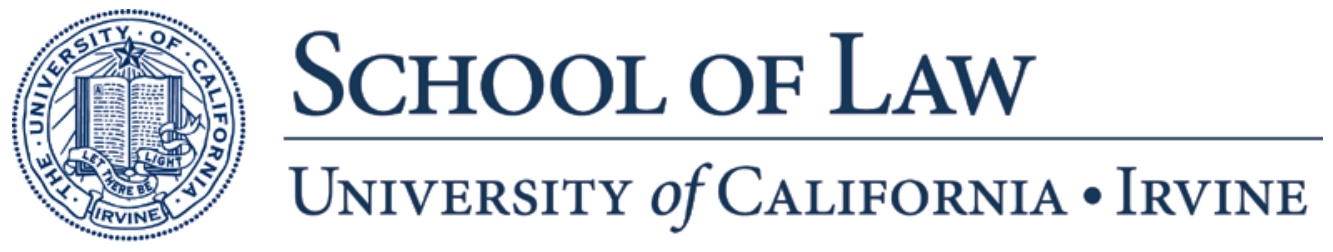

Legal Studies Research Paper Series No. 2013-94

ESSAY

\title{
IS "DEPENDENCE CORRUPTION" DISTINCT FROM $A$ POLITICAL EQUALITY ARGUMENT FOR CAMPAIGN FINANCE LAWS? \\ A REPLY TO PROFESSOR LESSIG
}

\author{
Richard L. Hasen \\ rhasen@law.uci.edu
}

University of California, Irvine School of Law 
ESSAY

\title{
IS “DEPENDENCE CORRUPTION” DISTINCT FROM A POLITICAL EQUALITY ARGUMENT FOR CAMPAIGN FINANCE LAWS? A REPLY TO PROFESSOR LESSIG
}

\author{
RICHARD L. HASEN ${ }^{*}$ \\ I. \\ INTRODUCTION
}

I greatly appreciate Professor Lawrence Lessig's interest in and passion about limiting the corrosive role of money in American politics. Lessig is an academic rock star, a great online and social media presence who draws large crowds for his multimedia presentations wherever he goes to talk about reforming our campaign finance system. He has done more to educate the general public about these issues than anyone else (aside from possibly Stephen Colbert), certainly more than those of us, like me, who have spent our entire careers writing about campaign finance issues.

And yet I have unease about a central premise of Lessig's argument: that "dependence corruption," the government interest he advances to support the constitutionality of his proposed campaign finance reforms, is analytically distinct from an interest in promoting political equality. Lessig's argument is crucial to the constitutionality of his program before the current Supreme Court, which has rejected political equality as a permissible interest to support campaign finance regulation. I recently discussed my concerns about the dependence corruption argument in a Harvard Law Review book review ${ }^{1}$ of Lessig's new book, Republic, Lost, and Lessig has responded with a defense in a Harvard Law Review Forum Reply $^{2}$ and in his public presentations. ${ }^{3}$

\footnotetext{
* Chancellor's Professor of Law and Political Science, UC Irvine School of Law. Thanks to Bruce Cain, Sarah Lawsky, Dan Lowenstein, David Strauss, and Zephyr Teachout for useful comments and suggestions.

${ }^{1}$ Richard L. Hasen, Fixing Washington, 126 HARV. L. ReV. 550 (2012) (reviewing LAWRENCE LESSig, RePUBlic, LOST (2011) and JACK ABRAMOFF, CAPITOL PUNISHMENT (2011)).

${ }^{2}$ Lawrence Lessig, A Reply to Professor Hasen, 126 HARV. L. REV. F. 61 (2012).

3 A video of Lessig's January 25, 2013 presentation at the University of Texas, Austin's conference, "Is America Governable?," is posted on YouTube at: http://youtu.be/dbdqFdw9NH8 [hereafter Lessig Video]. After I posted a draft of this article on SSRN, Lessig wrote a further Reply, What an Originalist Would Understand "Corruption" to Mean], CAL. L. Rev.
} 
My continuing concern is not primarily with Lessig's prediction that a current majority of the Supreme Court could well accept the dependence corruption rationale to justify new restrictions, such as contribution limits to super PACs-although I do think he is wrong in that prediction and that in his role as campaign finance reform zealot, he gives false hope to those who think the Court would soon effectively overturn Citizens United v. FEC ${ }^{4}$ using his analysis. Rather, Lessig's dependence corruption argument encourages fuzzy thinking about the political equality rationale at a time when we need clear thinking about, and defenses of, political equality arguments. There could well be a time within the next decade when a more liberal Supreme Court majority may consider overturning recent precedent and allowing more regulation. By being more precise about what is at stake with such regulation, and the potential costs to free expression, supporters of reasonable campaign finance regulation will be better positioned to defend a new set of laws. In the end, the debate over dependence corruption helps elucidate the best and worst types of political equality arguments to advance to a future Supreme Court and American public.

II.

\section{DEPENDENCE CORRUPTION AS DisTINCT FROM POLITICAL EQUALITY: THE DeBATE THUS FAR}

Campaign finance laws are complex, and the United States Supreme Court's pronouncements on the constitutionality of various campaign finance laws and regulation add layers of complexity which torment students and professors of election law alike. At the risk of caricature, here is the basic current state of constitutional doctrine as it pertains to campaign finance. ${ }^{5}$

Limits on the amount of money which individuals or entities spend in candidate elections $^{6}$ or contribute to candidates, parties, or groups raise First Amendment concerns because they impose a burden on free speech and association. The Court has recognized only the interest in preventing corruption

\footnotetext{
(forthcoming 2013), draft available at http://papers.ssrn.com/sol3/papers.cfm?abstract_id=2257948 [hereinafter, Lessig, Originalist].

558 U.S. 310 (2010).

${ }^{5}$ For a detailed exploration of these issues, see DANIEL HAYS LOWENSTEIN, RICHARD L. HASEN, \& DANIEL P. TOKAJI, ELECTION LAW-CASES AND MATERIALS chs. 12-16 (5th ed. 2012).

${ }^{6}$ The analysis differs somewhat for ballot measure elections, but I ignore these issues because they are irrelevant to this Essay.
} 
and the appearance of corruption to justify limits on the use of money in elections. ${ }^{\text {? }}$

While the anticorruption interest may be somewhat broader than preventing quids pro quo and other bribery-like conduct, it is not much broader. The Supreme Court's views of what counts as "corruption" has ebbed and flowed over time, ${ }^{8}$ and once included the concern that elected officials might be "too compliant" with the wishes of contributors. ${ }^{9}$ But no longer. Under current Supreme Court doctrine, corruption does not extend even to the sale of access to elected officials and candidates in exchange for campaign contributions or fundraising activities; as the Court recently explained in the controversial Citizens United case, ingratiation and access are not corruption. ${ }^{10}$

The Court has justified contribution limitations to candidates on anticorruption grounds: limiting contributions helps insure that elected officials do not take official action in exchange for large contributions. ${ }^{11}$ But the Court in Citizens United has rejected an anticorruption interest to justify limits on truly independent spending, reasoning that independent spending done without a candidate's cooperation or consultation can neither corrupt nor create the appearance of corruption. $^{12}$

Relying on this reasoning, the United States Court of Appeals for the District of Columbia Circuit in a case called SpeechNow struck down a limit on contributions to committees which spend independently of candidates. ${ }^{13}$ The court reasoned that if independent spending can never corrupt or create the appearance of corruption, contributions to fund such spending cannot be justified on

${ }^{7}$ See Buckley v. Valeo, 424 U.S. 1 (1976). Additional interests may justify disclosure laws, such as providing relevant information to voters. See LOWENSTEIN, HASEN, \& TOKAJI, supra note 5, ch 16. But that issue is also irrelevant to this Essay.

${ }^{8}$ See Richard L. Hasen, Citizens United and the Illusion of Coherence, 109 MicH. L. REV. 581 (2011); Richard L. Hasen, Beyond Incoherence: The Roberts Court's Deregulatory Turn in FEC v. Wisconsin Right to Life, 92 MinN. L. REV. 1064 (2008); Richard L. Hasen, The Newer Incoherence: Competition, Social Science, and Balancing in Campaign Finance Law After Randall v. Sorrell, 68 OHIO ST. L.J. 849 (2007); Richard L. Hasen, Buckley is Dead, Long Live Buckley: The New Campaign Finance Incoherence of McConnell v. Federal Election Commission, 153 U. PA. L. REV. 31 (2004).

${ }^{9}$ Nixon v. Shrink Mo. Gov. PAC, 528 U.S. 377, 389 (2000).

${ }^{10}$ Citizens United, 558 U.S. at 359-360.

${ }^{11}$ Buckley, 424 U.S. at 26-28.

${ }^{12}$ Citizens United, 558 U.S. at 357.

13 SpeechNow.org v. FEC, 599 F.3d 686 (D.C. Cir. 2010), cert. denied Keating v. FEC, 131 S.Ct. 553 (2010). 
anticorruption grounds either. ${ }^{14}$ This is the ruling which led to the emergence of Super-PACs and similar organizations. ${ }^{15}$

Promoting political equality —at least in the form of leveling the playing field-has not fared well at the Supreme Court as an interest justifying campaign finance limits. The Court in the key 1976 case Buckley v. Valeo rejected an equalization rationale as "wholly foreign" to the First Amendment. ${ }^{16}$ In Citizens United the Court reaffirmed this point. It overturned a 1990 Supreme Court case, ${ }^{17}$ Austin v. Michigan Chamber of Commerce, ${ }^{18}$ which upheld a requirement that corporations use a political action committee rather than the corporation's general treasury funds to spend to support or oppose candidates for office in the state of Michigan. The Court majority in Austin had justified the state's interest in barring the use of corporate treasury funds in candidate elections by what it called the prevention of a "different type of corruption:" "the corrosive and distorting effects of immense aggregations of wealth that are accumulated with the help of the corporate form and that have little or no correlation to the public's support for the corporation's political ideas.”19

I have long characterized this Austin interest as one not about corruption prevention but about promoting political equality by preventing corporate spending from distorting electoral or legislative outcomes. ${ }^{20}$ In his concurring opinion in Citizens United, Chief Justice Roberts cited my work and others' work reading Austin in this way, concluding that the Austin antidistortion interest was an equality interest. ${ }^{21}$ The Chief Justice (and the Court) rejected it on that basis. The Court reaffirmed its rejection of an equality interest in a recent case, Arizona Free Enterprise Club v. Bennett, ${ }^{22}$ involving Arizona's public financing system, which gave participating candidates extra public funds when facing large spending from opposing candidates or third-party groups.

Lessig wants to reduce the role of money in politics through a set of legislative reforms which he claims would survive a constitutional challenge. In Republic, Lost and in his public lectures about reform, Lessig has made it clear

${ }^{14}$ Id. at 694-95.

15 Richard L. Hasen, The Numbers Don't Lie, Slate (Mar. 9, 2012), http://www.slate.com/articles/news_and_politics/politics/2012/03/the_supreme_court_s_citizens_u nited_decision_has_led_to_an_explosion_of_campaign_spending_html.

${ }^{16}$ Buckley, 424 U.S. at $48-49$.

${ }^{17}$ Citizens United, 558 U.S. at 365.

${ }^{18} 494$ U.S. 652 (1990).

${ }^{19} \mathrm{Id}$. at 660 .

${ }^{20}$ Richard L. Hasen, The Supreme Court and Election LaW: Judging Equality From BAKER V. CARR TO BUSH V. GORE 113 (2003).

${ }^{21}$ Citizens United, 558 U.S. at 381 n.2 (Roberts, C.J., concurring).

${ }^{22} 131$ S.Ct. 2806, 2825 (2011). 
that he favors not only public financing of congressional campaigns via vouchers to empower voters. but also limits on contributions to independent groups involved in candidate elections. ${ }^{23}$ In other words, he wants to shut down the Super PAC option opened by Citizens United and SpeechNow. How can such limitations be constitutionally justified under the Supreme Court's current campaign finance jurisprudence?

In Republic, Lost, Lessig justified his proposals with reference to what he terms "dependence corruption," a type of corruption which he says is analytically distinct from the bribery-like corruption (which Lessig terms "Type 1" corruption) accepted by the Supreme Court to justify contribution limits to candidates. ${ }^{24}$ "In this second sense of corruption, it is not individuals who are corrupted within a well-functioning institution. It is instead an institution that has been corrupted, because patterns of influence operating upon individuals within that institution draws them away from the influence intended."25

As I explained in my earlier Review, Lessig tellingly uses passive voice to describe this type of "corruption:”

the "institution" of government "has been corrupted"-by whom he does not say. It is a "corruption" not in that lobbyists or others give legislators gifts in exchange for official action, but one in which the system "distort[s]" outcomes. ${ }^{26}$

Lessig explains that the "real risk" to the political system arises thanks to contributions funneled through lobbyists: "Influence happens on the margin, and the most powerful are the contributors who stand there."27 Even if lobbyist-driven contributions were small relative to other contributions, "if it provided a reliable and substantial source of funds, then its potential to distort policy would be huge."28

I concluded in my initial review that Lessig's concern about distortion of policy outcomes caused by the spending of money sounded a whole lot like Austin's political-equality-masquerading-as-corruption rationale, which the Supreme Court rejected in Citizens United. ${ }^{29}$ Lessig expressed concern that those

${ }^{23}$ Lessig Video, supra note 3.

${ }^{24}$ LESSIG, supra note 1 , at 17-20.

${ }^{25} \mathrm{Id}$. at 231.

${ }^{26}$ Hasen, supra note 1, at 571 (footnotes omitted).

${ }^{27}$ LESSIG, supra note 1 , at 121.

${ }^{28}$ Id.

${ }^{29}$ Hasen, supra note 1, at 572. I also suggested that part of his rationale sounded like an efficiency rationale; in this view campaign finance facilitates rent-seeking and can cause an economic 
with money and superior fundraising abilities can use these tools to have greater influence than everyone else over political outcomes. This looks like a concern about the wealthy using their wealth to skew political outcomes, a type of political equality argument.

In his reply to my review, Lessig devotes three-quarters of his space (9 of 12 pages) to refute my claim that dependence corruption is a type of political equality argument. ${ }^{30}$

Lessig begins by making a point with which I agree: a campaign finance law justified on traditional anticorruption grounds should not become unconstitutional if the law incidentally promotes political equality. ${ }^{31}$ For example, a law limiting individuals to $\$ 1,000$ candidate contributions in an election is justified on anticorruption grounds, but it also may level the playing field by limiting the most direct form of influence over politicians.

In support of this non-controversial point, Lessig begins with the premise that 'if 'money is speech,' then certainly 'votes are speech' too. Yet when the Court invalidated hundreds of years of election law governing the drawing of legislative districts, it was for the explicit purpose of equalizing that speech -

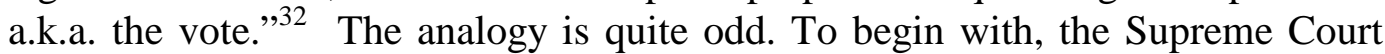
has rejected the idea that voting has expressive value protected by the First Amendment, ${ }^{33}$ although it recently seemed to back off from a strict statement of this point. ${ }^{34}$ More importantly, the voting analogy is off the mark: in challenges to

decline. Id. at 572-73. Lessig does not address this point in his response and I do not write further about it here.

${ }^{30}$ Lessig, supra note 2 . In the remaining third of his Reply, he makes two points. First, while he concedes that the existing evidence shows that public trust does not seem to rise with the enactment of campaign finance reform plans thus far, "that doesn't mean that a more trustworthy system wouldn't increase the public's trust.” Id. at 72. Second, while conceding he does not "have the data to support any causal link" between money spent on politics and a rise in political polarization," id. at 73, he argues that a voucher system could strengthen moderates at the expenses of extremists in politics. "Could, not necessarily would." Id. at 74.

${ }^{31} \mathrm{Id}$. at 62. While I agree with the normative point, it is not clear that this is how the current Court sees things: the Supreme Court in Bennett seemed to reject the Arizona public financing plan because the people may have been motivated to level the playing field in passing it. Lessig similarly argues that the Supreme Court did not mean to “demonize 'equality' in general, or banish as a compelling interest any interest that might also happen to correlate, in part at least, with equality." Id. at 63.

${ }^{32} \mathrm{Id}$. at 62.

${ }^{33}$ See Burdick v. Takushi, 504 U.S. 428, 438 (1992) (“Attributing to elections a more generalized expressive function would undermine the ability of States to operate elections fairly and efficiently”); Timmons v. Twin Cities Area New Party, 520 U.S. 351, 363 (1997) ("Ballots serve primarily to elect candidates, not as forums for political expression”); Adam Winkler, Note, Expressive Voting, 68 NYU L. REV. 330 (1993).

${ }^{34}$ Doe v. Reed, 130 S.Ct. 2811, 2818 n.1 (2010). 
malapportioned districts, the Court has accepted political equality as a compelling interest to require the creation of equally weighted voting districts. ${ }^{35}$ Political equality is not a side effect of the Court's one person, one vote jurisprudence but rather its defining feature. In contrast, political equality issues arise in campaign finance cases as a possible justification for potential infringement of First Amendment speech and association rights.

In any case, Lessig's point about incidental legislative motive to equalize voting power and his analogy to "voting as speech" is tangential to his main goal of refining and defending his notion of dependence corruption. He begins his main argument by defining “dependence corruption" (even providing us with a pronunciation guide: “de-pen·dence cor·rup·tion \di-'pen-dəns kə-'rəp-shən\ noun") as "the state of an institution or an individual that has developed a dependence different from a, or the, dependence intended or desired." ${ }^{\text {} 36}$ Distortion of policy is an effect of dependence corruption and not the "pathology" itself. ${ }^{37}$ Once again, passive voice dominates the definition: an institution is in a state of corruption when there is a gap between developed dependence and dependence desired-but the definition does not tell us who must desire a particular type of dependence.

${ }^{35}$ See, e.g. Reynolds v. Sims, 377 U.S. 533, 562 (1964):

Legislators represent people, not trees or acres. Legislators are elected by voters, not farms or cities or economic interests. As long as ours is a representative form of government, and our legislatures are those instruments of government elected directly by and directly representative of the people, the right to elect legislators in a free and unimpaired fashion is a bedrock of our political system. It could hardly be gainsaid that a constitutional claim had been asserted by an allegation that certain otherwise qualified voters had been entirely prohibited from voting for members of their state legislature. And, if a State should provide that the votes of citizens in one part of the State should be given two times, or five times, or 10 times the weight of votes of citizens in another part of the State, it could hardly be contended that the right to vote of those residing in the disfavored areas had not been effectively diluted. It would appear extraordinary to suggest that a State could be constitutionally permitted to enact a law providing that certain of the State's voters could vote two, five, or 10 times for their legislative representatives, while voters living elsewhere could vote only once. And it is inconceivable that a state law to the effect that, in counting votes for legislators, the votes of citizens in one part of the State would be multiplied by two, five, or 10, while the votes of persons in another area would be counted only at face value, could be constitutionally sustainable.

${ }^{36}$ Lessig, supra note 2, at 65.

37 “But I am not 'writing more about a distortion,' even if 'a distortion' is the consequence of what I am writing about — just as a book about alcoholism is not 'writing about liver failure,' even if liver failure is an effect of alcoholism. Hasen has confused a consequence with the pathology." Id. at 64 . 
Lessig explains that in the context of campaign finance regulation, the dependence "intended or desired" of elected officials is a dependence "on the people alone" - a phrase he draws from The Federalist No. 52. ${ }^{38}$ However, in our current political system elected officials are dependent not just upon the people but also upon "the funders"- those who provide the bulk of the money for campaigns. In his multimedia talks, he calls the funders "the Lesters" who live in "Lesterland" and who get to vote in a Lester-only primary to winnow the set of candidates to be chosen in general elections conducted among all "the people."39

The Lesters (or funders) constitute the very small fraction of people in the country who contribute or spend money on elections. Candidates need funders' money in this invisible wealth primary and "[t]hat need is a dependence." 40 The wealth primary, which narrows the field of candidates who run in the general election, makes elected officials dependent on the funders and not "upon the people alone.”

Lessig then explains why he believes dependence corruption is "distinct from the aim to 'level the playing field' (the more precise statement of the 'equality' sin identified by the Court in Bennett)." 41 He says that one can remedy dependence corruption without leveling the playing field. For example, he says that his proposed voucher program (which is similar to a voucher program I proposed in $1996^{42}$ ) would not "level the playing field" because the result would not be equality of campaign funding for all candidates. ${ }^{43}$

Further, he states that not all attempts to level the playing field deal with the dependence corruption problem. A law that bans union get-out-the-vote efforts might level the playing field when it comes to organizational benefits, but such a law would not be justified by an interest in insuring that "the people alone" choose representatives. $^{44}$ He concludes that “'[d]ependence corruption’ is thus not the inequality corruption in Austin. Neither is it the more general corruption that runs under the moniker 'political equality.",45 Instead, “'dependence corruption' is a distinct concept of corruption that points to the relationship between a dependence intended and the dependence realized. . . . [I]t is missing

\footnotetext{
${ }^{38} \mathrm{Id}$. at 65 . See infra note 78 and accompanying text (describing context for phrase in Federalist No. 52).

${ }^{39}$ Lessig Video, supra note 3.

${ }^{40}$ Lessig, supra note 2, at 65.

${ }^{41} \mathrm{Id}$. at 66.

${ }^{42}$ Richard L. Hasen, Clipping Coupons for Democracy: An Egalitarian/Public Choice Defense of Campaign Finance Vouchers, 84 CALIF. L. REV. 1 (1996).

${ }^{43}$ Lessig, supra, note 2, at 66.

${ }^{44} \mathrm{Id}$. at 67.

${ }^{45} \mathrm{Id}$.
} 
the point to reject the conception by arguing that it is really " 'distortion of policy outcomes, or skew.",46

Dependence corruption is a problem, Lessig explains, because "a reasonable citizen could believe that the candidates have become distracted" by the large search for money. ${ }^{47}$

The dynamic of representative government —in which representatives are responsive to all citizens - has been undermined by a system that makes representatives responsive to funders first, and only then to citizens. That is a plain corruption of the system of influence the Framers intended. It should be a plainly constitutional target for congressional reform. ${ }^{48}$

Lessig concludes by explaining how the Supreme Court could consider dependence corruption as a compelling interest to justify additional campaign finance regulation. Such recognition would not require the Court to overrule Citizens United, which considered only whether the usual anticorruption and antidistortion arguments justified a ban on direct spending of corporate general treasury funds. Indeed, given that the facts of Citizens United sought to stop a nonprofit filmmaker from spending its corporate funds to promote its own film (apparently not violating the idea that "the people alone" choose elected officials), Lessig believes the Court reached the right result. ${ }^{49}$ But he claims that preventing dependence corruption could justify reversing SpeechNow to restore the $\$ 5,000$ individual contribution limits to political action committees, thereby ending super PACs. "If the last three years [since Citizens United] have demonstrated anything, it is that the removal on limits on contributions to political action committees, whether independent or not, only increases the gap between 'the people' and 'the funders.",50

Lessig contends that while independent spending in candidate elections would not necessarily meet the definition of dependence corruption if such

\footnotetext{
${ }^{46} I d$. at $67-68$.

${ }^{47}$ Id. at 68.

${ }^{48} I d$.

${ }^{49}$ Id. Lessig does not acknowledge that under the law as it existed before Citizens United, a nonprofit ideological corporation which took no for-profit corporate or labor union money already was constitutionally exempt from corporate spending limits in candidate elections. FEC v. Mass. Citizens for Life, 479 U.S. 238 (1986). Citizens United could not take advantage of this exemption because it deliberately took some for-profit corporate money to create a test case. See Hasen, Illusion of Coherence, supra note 8, at 591 n.59. It was a camel's nose in the tent to get the forprofit corporate spending limit eliminated.

${ }^{50}$ Lessig, supra note 2, at 69.
} 
spending were "sporadic," 51 the regular mega-contributions to Super-PACs in the 2012 elections show that elected officials "understand themselves to be dependent" upon large contributors to independent political committees. He does not say whether a Congress similarly concerned about dependence corruption from independent spending (if the Super-PAC option ended) could bar Sheldon Adelson from directly spending vast sums of his money on advertising, if the government could show that elected officials understand themselves to be dependent upon large independent spenders. Nor does he say how his program could be effective without this additional limitation. That is, Lessig's logic leaves open the possibility of reversing Buckley's ban on independent expenditure limits applied to individuals.

Lessig concludes by predicting that the Supreme Court could well accept his dependence corruption argument to justify limits on contributions to independent expenditure committees. He says that at least one Justice committed to originalism in the Supreme Court majority (but not Justice Scalia) could switch positions from Citizens United and vote with the more liberal Supreme Court Justices to uphold additional campaign finance regulations. ${ }^{52}$

\section{III. \\ Lesters ARE PEOPle, MY Friend: ${ }^{53}$ DePENDENCE CORRUPTION AS A TyPE OF POLITICAL EQUALITY ARGUMENT}

Lessig's dependence corruption rationale depends entirely upon a distinction between "the people alone" and "the funders" (or the "Lesters"). The "system" is "corrupted" when elected officials are dependent not on "the people alone" but also on "the funders"/"Lesters."

But who are the funders? In Lessig's multimedia presentation, "the Lesters" look vaguely like the "Smithers" character from The Simpsons. ${ }^{54}$ Smithers is the flunky for the richest man in town, nuclear power plant owner Mr. Burns - and Smithers is secretly in love with Mr. Burns and his great wealth Whatever is true in Lesterland, here on Planet Earth "the funders" are certainly

\footnotetext{
${ }^{51} I d$.

${ }^{52}$ See id. at 70-71.

${ }^{53}$ With apologies to Mitt Romney. See Philip Rucker, Romney Says 'Corporations are People' at Iowa State Fair, WASH. PosT (Aug. 11, 2011), http://articles.washingtonpost.com/2011-0811/politics/35270239_1_romney-supporters-mitt-romney-private-sector-experience

(““Corporations are people, my friend,' Romney said”).

${ }^{54}$ Lessig video, supra note 3, at 7:05. Lessig explains that his real first name is not Lawrence but Lester, justifying his picking on the Lesters. Id.
} 
part of "the people." The people funding campaigns are (generally more wealthy) American citizens, permanent residents, and (as of Citizens United) now American corporations, labor unions, and other entities who spend money on candidate campaigns and give to Super-PACs and 501c's. ${ }^{55}$

To put Lessig's argument another way, Lessig objects that a (generally wealthier) subset of "the people" in the United States have greater influence over the outcome of federal elections or over federal public policy than another, much larger subset of "the people" do. This greater influence over elections or policy is the source of the distortion or skew, explaining why political outcomes sometimes do not match majoritarian preferences. Lessig further objects that "the people," upon learning of the oversized influence of (wealthy) funders over elected officials will lose trust in a political system.

Putting aside the trust point for now, Lessig's argument is fairly characterized as a political equality argument. A political equality argument is one which seeks to justify a law on grounds that it distributes political power fairly or seeks to attack a law in court on grounds that it distributes political power in an unequal way. The problem with malapportioned legislative districts, as struck down in the Supreme Court's one person, one vote cases, is that such districts treated people unequally by giving some people much more voting power than others.

Lessig's dependence corruption argument is a political equality argument because it seeks to justify campaign finance laws on grounds that the laws distribute political power fairly and correct a distortion present in an unregulated (or less regulated) system. His concern is that some people in society have greater influence over election results and legislative results in Congress than others based solely upon their wealth and fundraising abilities. The gap between what "the people" want and what "the funders" want is the source of the inequality. The wealthy in this way are similar to pre-Baker v. Carr voters in sparsely-populated districts who had more voting power than voters in big cities. ${ }^{56}$

\footnotetext{
55 "The people" do not include foreign individuals and entities (aside from permanent residents), and existing law (recently reaffirmed by the Supreme Court) bars foreigners from giving or spending money in our elections. Bluman v. FEC, 132 S.Ct. 1087 (2012) (mem.), affirming 800 F. Supp. 2d 281 (D.D.C. 2011) (three-judge court); LOWENSTEIN, HASEN, \& TOKAJI, supra, note 3, at 756-57. "The funders" include voters and other "people" who are U.S. citizens and permanent residents. Lessig does not object to corporate involvement in elections per se. In his video presentation he rejects calls to reverse Citizens United and simply bar corporate spending in elections, arguing it would not stop the problem of dependence corruption.

56 The analogy is not precisely the same. In Lessig's example, the funders exert their greater influence through the invisible wealth primary, while in malapportioned districts the voters in smaller districts exert greater power over legislators in a legislative body.
} 
Here is how we know Lessig's argument is one about equality rather than corruption. Under Lessig's voucher plan, where voters have equal capital to spend on elections, elected officials are dependent upon a subset of the people as wellthose who use vouchers to support the candidate, or her party, or interest groups backing the candidate. As under the current system, elected officials depend upon a subset of the people for support, and presumably are more responsive to the needs of these funders than to all of the people. Yet this skewed responsiveness is not a form of "dependence corruption:” indeed Lessig proposes vouchers to end dependence corruption. What is objectionable about the current system, then, is not that elected officials are beholden and responsive to a subset of voters but that they are beholden to a subset of wealthy and well organized voters whose interests do not align with the interests of voters overall.

Lessig is right that his argument differs in some particulars from the equality argument in Austin, But even Lessig recognizes that there are different types of equality arguments, ${ }^{57}$ and therefore his ability to distinguish dependence corruption from Austin antidistortion does not disprove the point that dependence corruption is also an equality argument.

Austin advances what I've termed a "barometer equality" argument ${ }^{58}$ - the idea that that the amount spent on elections should roughly correlate with public's support for the candidates funded, at least when it comes to the question of corporate funding. Lessig does not argue precisely for Austin equality-his argument is not one primarily about corporations, for example-but he also rejects outsized influence by wealthy contributors and spenders. Like Austin's antidistortion, Lessig's dependence corruption interest argues for a system in which spending on elections is somehow tied to public support for candidates. Vouchers insure that candidates are funded in a way reflecting popular interest-a rough barometer of popular support. Indeed, that is why I support them.

\footnotetext{
${ }^{57}$ He calls the equality "sin” in Bennett one about "leveling the playing field." Lessig, supra note 2 , at 66. In his most recent response in this dialogue, Lessig continues to insist that dependence corruption is not an equality argument. In making his argument that it is corruption, not inequality, when the "Lesters" get to participate in the wealth primary, he analogizes primaries conducted in which the voters are all white, or where the sole primary voter is the Queen of England, or where the state Senators get to choose who could run to be members of Congress. Lessig, Originalism, supra note 3 at 19-22. Without rehashing all the arguments in the text above, all of Lessig's examples are objectionable (for among other reasons) because of inequality, not because of corruption. Indeed, I always thought that was the point of the White Primary cases.

${ }^{58}$ HASEN, supra note 20, at 113.
} 
To put the point more generally, political equality arguments come in three varieties: political input, political output, and political opportunity. ${ }^{59}$ Some political equality arguments support political systems in which each voter has roughly equal political power to influence who is elected to office. The one person, one vote rule and campaign finance voucher plans may each seek to insure equality of political inputs. In a voucher system like Lessig's, each voter's political power is roughly the same but each candidate's political power will vary depending upon the amount of public voucher support.

Others argue for political systems equalizing political outputs: a public financing system giving each candidate (rather than each voter) roughly equal political funding seeks to equalize political outputs. Major party candidates in presidential elections can opt into a public funding plan modeled along these lines. Both an input and an output campaign finance plan might "level the playing field" depending upon how we define the "field:" input arguments level the field among voters while output arguments level the field among candidates.

Political systems also might promote equality by insuring equality of political opportunity — providing a floor of public financing for all candidates or parties, for example. The presidential public financing system provides matching funds for the first $\$ 250$ which presidential candidates raise in political primaries. It also allows minor parties who demonstrate some public support to get some public financing, although less than major party candidates. Heather Gerken's ${ }^{60}$ and Dorie Appollonio, Bruce Cain and Lee Drutman's ${ }^{61}$ separate proposals to subsidize public interest lobbying (without capping the lobbying activities of others) seek to insure equality of political opportunity. Lessig's earlier calls for his voucher plan fit into this category, because he was not interested in limiting outside spending. But with the rise of super PACs, he has now made a limit on contributions to independent groups a central part of his reform agenda and seems open to independent spending limits as well. ${ }^{62}$

\footnotetext{
${ }^{59}$ These categories have some overlap with but are not the same as categories Bruce Cain develops in Bruce E. Cain, Moralism and Realism in Campaign Finance Reform, 1995 U. CHI. LEGAL F. 111, 131-139 (discussing participation equity, influence equity, and outcome equity).

${ }^{60}$ Heather Gerken, Keynote Address: Lobbying as the New Campaign Finance, 27 GA. ST. U. L. REV. 1155, 1165-67 (2011).

${ }^{61}$ Dorie Apollonio et al, Access and Lobbying: Looking Beyond the Corruption Paradigm, 36 HASTINGS CONST. L.Q. 13, 48 (2008).

62 Lawrence Lessig, One Way Forward: The Outsider's Guide to Fixing the Republic (Kindle Single) (Kindle Location 708-09) (2012).
}

I used to believe that this change [to vouchers] would be enough. But the dynamic that we've seen over the past two years with super PACs has convinced me that we need something more. The government, in my view, should never have the power to ban the 
Thus, when Lessig says his dependence corruption argument is not an equality argument, or not a "level the playing field argument," because it does not fund all candidates equally, he is being unduly narrow in his definition of a political equality argument. Lessig's exhortation to restore contribution limits on independent political committees in the name of preventing dependence corruption is no less than a call to insure that the wealthy do not have disproportionate influence over electoral or legislative outcomes. It is a call for equality of political inputs. He seeks to reduce the voice of some to enhance the relative voice of others, something the Court in Buckley called an "equalization" rationale (and which the Court rejected as an impermissible basis for spending limits $\left.{ }^{63}\right)$.

There is one other way to think about Lessig's argument, though it is one he resists in his book and his talks: that he really is talking not about a "different" kind or corruption or political equality, but rather about normal "Type 1" corruption, akin to bribery. This point echoes and is informed by an important 1995 debate among Bruce Cain, Dan Lowenstein and David Strauss on the intersection of corruption and political equality in the context of an imaginary plan to equalize campaign funding with vouchers. ${ }^{64}$

To begin with, everyone agrees that if an elected official took $\$ 50,000$ from an individual and used it to buy a car in exchange for voting a certain way in the legislative body, this exchange would be considered corrupt and the government could bar the practice. Taking official action for private benefit is corrupt.

But what if an elected official voted a certain way in a legislative body in exchange for a $\$ 50,000$ campaign contribution - that is, exchanging a political, not a personal benefit for dollars? Is that corrupt? In the Lowenstein debate with

political speech of any individual or group, regardless of whether a citizen or not, or "a person" or not. Citizens, foreigners, corporations, and (someday, I hope) dolphins should be free to add their perspective to the political marketplace of ideas. But the recent experience with super PACs has convinced me that there must be an ability to limit the amount of independent expenditures that can be made in a campaign, so as to assure that candidates don't become just as dependent upon independent spenders as they are now dependent upon contributors. Limit, but not ban. Congress should be free to set reasonable limits to avoid improper dependence. It should not be free to silence any one faction in a debate.

${ }^{63}$ Buckley, 424 U.S. at 48-49.

${ }^{64}$ Cain, supra note 59; Daniel Hays Lowenstein, Campaign Contributions and Corruption: Comments on Strauss and Cain, 1995 U. CHI. LEgAL. F. 163; David A. Strauss, What is the Goal of Campaign Finance Reform?, 1995 U. CHI. LEGAL F. 141; see also David A. Strauss, Equality, Corruption, and Campaign Finance Reform, 94 CoLUM. L. REV. 1369 (1994). 
Strauss and Cain, Lowenstein saw this type of exchange as corrupt while Strauss and Cain saw the problem with such an exchange as one of political inequality.

To make matters more complicated, consider whether it is "corruption" when a $\$ 50,000$ campaign contribution (perhaps a contribution to a Super-PAC supporting a candidate) is used not for personal benefit and not to buy a legislative vote, but merely to influence the election official's agenda, insure access to the elected official to make a considered argument, or create conditions of ingratiation by building norms of reciprocity between the contributor and the elected official. Is this a problem of corruption or inequality? ${ }^{65}$

Some of the liberals on the Supreme Court want to call even this last case corruption-consider Justice Souter's admonition in Shrink Missouri that corruption occurs when elected officials are "too compliant" with the wishes of big donors. ${ }^{66}$ However, the conservative Supreme Court majority definitively has rejected this more expansive definition of corruption in Citizens United.

Not only has the Supreme Court rejected calling the excessive influence of large contributors over legislative outcomes a kind of corruption; Lessig resists as well. Lessig denies "dependence corruption” is about corrupt politicians, and he consistently talks about the "system" being corrupted and not the people in the system being corrupt. Thus, dependence corruption is "a corruption practiced by decent people, people we should respect, people working extremely hard to do what they believe is right, yet decent people working with a system that has evolved the most elaborate and costly bending of democratic government in our history. ${ }^{67}$ "[T] $[$ he term dependence corruption describes the process of governance. It doesn’t point to a particular tainted result."68 Thus, while there may be room for

${ }^{65}$ As Dan Lowenstein explained elsewhere, Daniel Hays Lowenstein, On Campaign Finance Reform: The Root of All Evil is Deeply Rooted, 18 HOFSTRA L. REV. 301 (1989), the most sensible way of thinking of the problem of large contributions buying influence but not outcomes is that it creates an actuality of a conflict of interest among legislators who are charged with acting in the public interest.

${ }^{66}$ Nixon v. Shrink Mo. Gov. PAC, 528 U.S. 377, 389 (2000).

${ }^{67}$ Lessig, supra note 1, at 8; see also id. at 235 ("Each side subsidizes the work of the other (lobbyists by securing funds to members: members by securing significant benefits to the clients of the lobbyists). But that subsidy can happen without anyone intending anything in exchangedirectly. . . . People working within this system can thus believe-and do believe-that they're doing nothing wrong by going along with how things work").

In a more recent work, Lessig seems to recognize that "bad" people may be at play: "And thus, without even spending a dollar, the super PAC achieves its objective: bending congressmen to its program. It is a dynamic that would be obvious to Tony Soprano or Michael Corleone but that is sometimes obscure to political scientists: a protection racket that flourishes while our Republic burns.” $\square$ LESSIG, supra note 62, at Kindle Location 628.

${ }^{68}$ Lessig, supra note 1, at 17 n.6. 
calling Lessig's concern one about traditional corruption, both the Supreme Court and Lessig have resisted.

As least in this instance (although not in the case of the campaign contribution/legislative vote quid pro quo) I come down on the Strauss/Cain side of the line and see the concern about large contributions influencing (but not buying) outcomes as one more about political inequality and less about (traditional) corruption. The point is debatable, but even calling it "corruption" would not help much if the audience is the current Supreme Court.

Finally, rather than embrace political equality or even traditional corruption to support his program, Lessig instead falls back on a trust argument: "The people" may lose trust in the political process because the people believe elected officials are too responsive to the interests of the funders rather than the public interest. This trust and responsiveness concern sounds a lot like a concern about either the appearance of corruption or an appearance of inequality. It is yet another argument the Supreme Court rejected in Citizens United ${ }^{69}$ and it does not appear to be an argument which can do the kind of heavy jurisprudential lifting Lessig needs to get past Citizens United's narrow view of corruption.

\section{IV. \\ Political EQUALITY, CAMPAign FinANCE, AND THE NEXT SUPREME COURT}

Suppose I am correct that Lessig's dependence corruption argument is really a political equality argument in disguise. Why does it matter?

To begin with, recognizing dependence corruption as a political equality argument should put to bed the notion that the current Supreme Court can be persuaded to reverse its Citizens United course and impose some limitations on independent spending (or contributions funding such spending) in candidate elections.

Last year, the Montana Supreme Court tried to buck the U.S. Supreme Court's decision in Citizens United by holding that the state of Montana provided enough evidence that independent corporate political spending could corrupt the state's political process to justify corporate spending limits. ${ }^{70}$ While the case was pending before the Supreme Court, Lessig was alone in predicting that the Supreme Court would take the case and affirm the lower court, with his betting on

\footnotetext{
${ }^{69}$ Lessig's response on the trust argument is weak. I had pointed to the work of Persily and Lammie demonstrating that there is no good correlation between campaign finance regulation and the public's trust. Lessig concedes the point, Lessig, supra note 2, at 72, "[b]ut that doesn't mean that a more trustworthy system wouldn't increase the public's trust.” Id.

${ }^{70}$ W. Tradition P'ship v. Montana, 271 P.3d 1 (Mont. 2011).
} 
Justice Kennedy switching sides from his Citizens United vote. ${ }^{71}$ The rest of us in the field predicted what actually happened: ${ }^{72}$ in American Tradition Partnership v. Bullock, ${ }^{73}$ the U.S. Supreme Court smacked down the Montana Supreme Court in a 5-4 summary reversal in which all the Justices in the Citizens United majority reaffirmed the soundness of that precedent.

But Lessig was undeterred by the ATP smackdown. As late as January 2013, months after the Montana case, he was predicting that an "originalist" Justice (but not Justice Scalia, for whom he clerked) could well reverse course on Citizens United in a future case. ${ }^{74}$ Lessig believes, following the work of Professor Zephyr Teachout, ${ }^{75}$ that "dependence corruption" is a form of corruption that would have been recognizable and accepted by the Framers as a legitimate basis to limit spending in elections. ${ }^{76}$

I leave to others the question whether or not the Lessig/Teachout interpretation of "corruption" to include concepts of political equality is consistent with originalist thinking. ${ }^{77}$ I will note however that in Federalist No. 52, the

${ }^{71}$ Corbin Hiar, Lawrence Lessig on Campaign Finance Reform: Overturning 'Citizens United' Isn't Enough, THE CENTER FOR PUBLIC INTEGRITY (Feb. 29, 2012), http://www.publicintegrity.org/2012/02/29/8278/lawrence-lessig-campaign-finance-reformoverturning-citizens-united-isnt-enough:

After the speech, Lessig, who worked as a clerk for conservative Justice Antonin Scalia before becoming an academic, added that he was confident that Citizens United will soon be reversed by the high court.

"I think it’s quite likely Justice Kennedy is about to flip," he said, referring to the Supreme Court justice who cast the deciding vote in the controversial 5-to-4 decision. Although Lessig cautioned that he had no inside information, he said Kennedy "is completely surprised by how much damage this decision has done - even Scalia doesn’t like the world where all the money in the world is on one side."

72 See, e.g., Rick Hasen, Montana Citizens United Sequel on Supreme Court Docket for June 14: What's Next?, ELECTION LAW BLOG (May 29, 2012), http://electionlawblog.org/?p=34871 (calling summary reversal a "potentially likely outcome”).

73132 S.Ct. 2490 (2012).

${ }^{74}$ Lessig Video, supra note 3.

${ }^{75}$ See Zephyr Teachout, The Anti-Corruption Principle, 94 CORNELL L. REV. 341 (2009).

${ }^{76}$ Lessig, supra note 2, at 65, 70.

77 Teachout has debated Seth Barrett Tillman on these questions of originalism. See Seth Barrett Tillman, Opening Statement: Citizens United and the Scope of Professor Teachout's AntiCorruption Principle, 107 Nw. U. L. REV. 399 (2012); Zephyr Teachout, Gifts, Offices, and Corruption, 107 Nw. U. L. REV. Colloquy 30 (2012); Seth Barrett Tillman, The Original Public Meaning of the Foreign Emoluments Clause: A Reply to Professor Zephyr Teachout, 107 NW. U. L. REV. Colloquy 180 (2013). Lessig weighs in further on the originalist issue in Lessig, Originalism, supra note 3. Bruce Cain responds to Lessig on originalism, casting serious doubt on his reading of the Founders' intent, in Bruce Edward Cain, Is Dependence Corruption the Solution 
phrase "dependent upon the people alone" appears in a passage explaining why the Constitution set the qualifications for suffrage pertaining to voting for members of the U.S. House the same as the qualifications for voting for the state legislature. Publius states that allowing the state legislature the discretion to set the rules for voting for Congress "would have rendered too dependent on the State Governments, that branch of the federal government which ought to be dependent on the people alone."78 The language here has everything to do with federalism and the federal-state balance, and nothing to do with improper influence by those with money or other benefits over the Congress. Later in the pamphlet, Publius explains that biennial elections insures that Congress will be properly dependent on the people: "Frequent elections are unquestionably the only policy by which this dependence and sympathy can be effectually secured."79 There is no hint in this Federalist Paper about worries of monied classes influencing the people in their votes for Congress.

Regardless of the soundness of the originalist debate, the idea that the current Supreme Court will change course thanks to an undiscovered originalist argument is a pipe dream. Justice Thomas has been the Justice most hostile to campaign finance regulation in his time on the Court, leading the way toward deregulation, ${ }^{80}$ with Justice Alito closely following suit. ${ }^{81}$ Justice Kennedy has never wavered from his dissents in Austin, in which he said that the Michigan law limiting corporate spending in elections to PACs "is the rawest form of censorship," ${ }^{82}$ and in McConnell, in which he first declared that ingratiation and access are not corruption ${ }^{83}$ - a point he made into a majority opinion in Citizens United. ${ }^{84}$ And Chief Justice Roberts has yet to vote to uphold a campaign finance limit while on the Court; his opinions have lamented FEC regulation as speech suppression, declaring “enough is enough." 85

to America's Campaign Finance Problems?, CAL. L. REV. (forthcoming 2013), draft available, http://papers.ssrn.com/sol3/papers.cfm?abstract_id=2267187.

${ }^{78}$ THE FEDERALIST No. 52, at 323 (James Madison) (Clinton Rossiter ed., 1991).

${ }^{79} \mathrm{Id}$.

${ }^{80}$ Richard L. Hasen, Justice Thomas: Leading the Way to Campaign-Finance Deregulation, FIRST $\begin{array}{lllll}\text { AMENDMENT CENTER ONLINE } & \text { (Oct. }\end{array}$ http://www.firstamendmentcenter.org/analysis.aspx?id=18958.

${ }^{81}$ Justice Alito has voting to strike down or limit every campaign finance law to come before him on the Supreme Court, and has expressed serious misgivings about the constitutionality of campaign finance disclosure. Doe v. Reed, 130 S.Ct. 2811, 2822-2827 (Alito, J., concurring).

${ }^{82}$ Austin, 494 U.S. at 700 (Kennedy, J., dissenting).

${ }^{83}$ McConnell v. FEC, 540 US. 93, 294-95 (2003).

${ }^{84}$ Citizens United, 558 U.S. at 359.

${ }^{85}$ FEC v. Wisc. Right to Life, 551 U.S. 449, 478 (2007) (plurality opinion). 
This Supreme Court majority won't budge on this question despite original understandings of the meaning of "corruption," and arguing that it will gives supporters false hope.

So where does change come from? Agitating for a constitutional amendment to overturn Citizens United may be good politics for those on the left - who have made the case a symbol of Republican overreaching - but in a highly polarized Congress and country, there is virtually no chance barring a major national scandal that a super-majority of Congress and the states will support a constitutional amendment allowing spending limits in candidate elections.

Instead, the best way to change the First Amendment is to change the Supreme Court. Within a decade, it is quite likely that due to age Justice Scalia, Justice Kennedy, or both will leave the Court. The current Supreme Court's ideological divide is also party-based: thanks to polarization generally, all the conservatives on the Court were appointed by Republican presidents and all the liberals on the Court were appointed by Democratic presidents. ${ }^{86}$ The two newest members of the Court, Justices Kagan and Sotomayor, joined with Justices Breyer and Ginsburg to dissent in the Montana case arguing for Citizens United to be reconsidered. ${ }^{87}$ These four Democrat-appointed Justices also joined in a dissenting opinion authored by Justice Kagan in the Bennett campaign finance case. $^{88}$ A Democratic president in the next 10 years could well appoint the deciding fifth Justice who could reverse Citizens United.

But even if a Democratic president gets to appoint another Justice Kagan or Sotomayor to the Court, it is not clear that the Court will overturn Citizens United. Laws limiting money in elections can keep incumbents in office, and squelch political debate, points Justice Kagan recognized when she rejected Austin in writings as a law professor. ${ }^{89}$ The greatest danger of Super-PACs-that they skew legislative outcomes and priorities on non-salient public policy questions - is well hidden from public view, and regulation could be a hard sell to a skeptical court given its First Amendment costs.

Supporters of reasonable campaign finance regulation need to spend the time now crafting strong arguments which could sustain close judicial scrutiny.

${ }^{86}$ See Richard L. Hasen, End of the Dialogue? Political Polarization, The Supreme Court, and Congress, 86 S. CAL. L. REV. 205 (2013).

${ }^{87}$ Am. Tradition P'ship, 132 S.Ct. 2490 (2012).

${ }^{88}$ Bennett, 131 S.Ct. 2806, 2829 (2011).

${ }^{89}$ Elena Kagan, Private Speech, Public Purpose: The Role of Governmental Motive in First Amendment Doctrine, 63 U. CHI. L. REv. 413, 471 (1996) (recognizing and critiquing Austin equalization rationale). See also Richard L. Hasen, The Big Ban Theory: Does Elena Kagan Want to Ban Books? No, and She Might Even Be a Free-Speech Zealot, SlAtE (May 24, 2010), http://www.slate.com/articles/news_and_politics/jurisprudence/2010/05/the_big_ban_theory.html. 
Should all political equality arguments be on the table? Or are arguments for equality of inputs more justifiable than equality of outputs or equality of opportunity? How should the courts balance this interest in equality with concerns of squelched speech and incumbency protection? When does the attempt to insure that representatives are responsive to "the people" cross the line into impermissible censorship?

At first cut, input-equalizing campaign finance measures may present fewer First Amendment dangers than output measures. In these models, such as those using vouchers, political power resides with voters, not with candidates, and plans which equalize political power among voters is more likely to insure that campaign funding reflects voter preferences and insures a wide variety of voices, ideologies and opinions in campaigns and in legislative battles. Equal funding for candidates in an output-equalizing plan (depending on the permissibility of outside group spending) could more seriously limit the robustness of political debate, creating greater dangers of incumbency protection and the squelching of political speech. Opportunity-equalizing measures may present the lowest First Amendment dangers, through the use of floors without ceilings, but also may provide the fewest benefits in assuring political equality.

I hope that Lessig turns his considerable talents to addressing these thorny questions of political equality. It is no longer enough to point to the gap between the public interest and the interests of those who contribute, spend, and fundraise to gain disproportionate political influence. It is time for clear heads to build a new political equality architecture to support fair campaign finance laws ready to be assembled when the time comes. 